\title{
Species and tissue-specificity of prokinetic, laxative and spasmodic effects of Fumaria parviflora
}

\author{
Najeeb-ur-Rehman', Malik Hassan Mehmood ${ }^{1}$, Adnan J Al-Rehaily², Ramzi AA Mothana ${ }^{2,3}$ and Anwar H Gilani ${ }^{{ }^{*}}$
}

\begin{abstract}
Background: Fumaria parviflora Linn. (Fumariaceae), is a small branched annual herb found in many parts of the world including Saudi Arabia and Pakistan. This study was designed to provide pharmacological basis for the medicinal use of Fumaria parviflora in gut motility disorders.
\end{abstract}

Methods: The in-vivo prokinetic and laxative assays were conducted in mice. Isolated intestinal preparations (ileum and jejunum) from different animal species (mouse, guinea-pig and rabbit) were separately suspended in tissue baths containing Tyrode's solution bubbled with carbogen and maintained at $37^{\circ} \mathrm{C}$. The spasmogenic responses were recorded using isotonic transducers coupled with PowerLab data acquisition system.

Results: The aqueous-methanol extract of Fumaria parviflora (Fp.Cr), which tested positive for the presence of alkaloids, saponins, tannins and anthraquinones showed partially atropine-sensitive prokinetic and laxative activities in the in-vivo in mice at 30 and $100 \mathrm{mg} / \mathrm{kg}$. In the in-vitro studies, Fp.Cr (0.01-1 mg/ml) caused a concentrationdependent atropine-sensitive stimulatory effect both in mouse tissues (jejunum and ileum), and rabbit jejunum but had no effect in rabbit ileum. In guinea-pig tissues (ileum and jejunum), the crude extract showed a concentrationdependent stimulatory effect with higher efficacy in ileum and the effect was partially blocked by atropine, indicating the involvement of more than one types of gut-stimulant components (atropine-sensitive and insensitive). This could be a plausible reason for the greater efficacy of $\mathrm{Fp} . \mathrm{Cr}$ in gut preparations of guinea-pig than in rabbit or mouse.

Conclusions: This study shows the prokinetic, laxative and spasmodic effects of the plant extract partially mediated through cholinergic pathways with species and tissue-selectivity, and provides a sound rationale for the medicinal use of Fumaria parviflora in gut motility disorders such as, indigestion and constipation. This study also suggests using different species to know better picture of pharmacological profile of the test material.

\section{Background}

In traditional medicine, gut motility disorders such as, indigestion and constipation are considered root cause of ill health [1], where self-medication using natural products is common amongst the public [2]. It is not uncommon that constipation usually accompanies with indigestion and different classes of chemical drugs, such as prokinetics and laxatives are used in the conventional medicine for these disorders [3]. On the other hand, herbal remedies (known to contain multiple chemicals)

\footnotetext{
* Correspondence: anwar.gilani@aku.edu

'Natural Product Research Division, Department of Biological and Biomedical Sciences, The Aga Khan University Medical College, Karachi 74800, Pakistan Full list of author information is available at the end of the article
}

are considered relatively safe and useful in such disorders, thus a single plant offers multiple therapeutic benefits [4].

Fumaria parviflora Linn. (Fumariaceae), locally known in Saudi Arabia as 'Homaira', is a small branched annual herb found in many parts of the world including Middle East [5] and South Asia [6]. In the Greco-Arab (Unani) traditional medicine, the plant is widely used in gut disorders such as, indigestion, constipation, abdominal cramps and diarrhea $[5,6]$. However, the plant has not been studied for its medicinal use in indigestion or constipation except a preliminary in-vitro study showing a cholinergic activity on the part of another species (Fumaria indica) of this genus [7]. In this study, we

\section{() Biomed Central}


showed for the first time that Fumaria parviflora possesses prokinetic and laxative properties in the in-vivo models and the detailed study on the possible mode of action was carried out using the in-vitro experiments involving different species and tissues.

Phytochemical studies on Fumaria parviflora have shown the presence of alkaloids, such as, adlumidiceine, coptisine, fumariline, parfumine, protopine [8], fumaranine, fumaritine, paprafumicin, paprarine [9], fumarophycine, cryptopine, sanactine, stylopine, bicuculline, adlumine, perfumidine and dihydrosanguirine [10]. However to the best of our knowledge, none of the reported compounds or the parent plant has been studied for its laxative or prokinetic activity.

\section{Methods}

\section{Plant material}

The aerial parts of Fumaria parviflora were collected from Al-Souda area in Abha, Saudi Arabia in March, 2010. The plant was authenticated by Dr. Mohammad Yusuf, Taxonomist at the College of Pharmacy, King Saud University and the specimen has been preserved at the herbarium of the College of Pharmacy (voucher \# 15515), King Saud University, Riyadh, Saudi Arabia, and also at the Natural Product Research Division, Department of Biological and Biomedical Sciences, The Aga Khan University, Karachi with voucher \# Fp-AP-23-1099.

\section{Extraction procedure}

By following a previously described method [11], the aerial parts of Fumaria parviflora were soaked in the aqueous-methanol (30:70) for 3 days and filtered through muslin cloth and Whatman (Maidstone, UK) No.1 filter paper simultaneously. This procedure was repeated three times, and all the filtrates were pooled and evaporated in rotary evaporator (model RE-111, Buchi, Flawil, Switzerland) under reduced pressure to finally obtain the crude extract. The yield of thick dark brown past-like mass was $26.6 \% \mathrm{w} / \mathrm{w}$.

\section{Phytochemical screening}

Phytochemical investigation of the crude extract of Fp. $\mathrm{Cr}$ was carried out qualitatively for the presence of alkaloids, saponins, tannins and anthraquinones as plant constituents according to a standard method [12].

\section{Chemicals}

Acetylcholine perchlorate (ACh), atropine sulphate, carbachol $(\mathrm{CCh})$, histamine hydrochloride, 5-hydroxytryptamine (5-HT), pyrilamine maleate and hexamethonium chloride were purchased from Sigma-Aldrich Chemicals Company (St Louis, MO, USA). SB203186 (1-piperidinylethyl-1H-indole-3-carboxylate) was purchased from
Tocris (Ballwin, MO, USA). All chemicals used were of the analytical grade available and solubilized in distilled water.

\section{Animals}

BALB/c mice (weighing 20-25 g), guinea-pigs (weighing 400-600 g) and local breed rabbits (weighing 1-1.5 kg) of either sex, were housed at the animal house of the Aga Khan University under a controlled environment $\left(23-25^{\circ} \mathrm{C}\right)$. The animals were kept in respective standard cages and were fasted accordingly before starting the experiments, while in routine they had free access to feed and water. The experiments were performed with the rulings of the Institute of Laboratory Animal Resources, Commission on Life Sciences, National Research Council [13] and approved by the Ethical Committee of the Aga Khan University.

\section{In-vivo experiments \\ Charcoal meal gut transit test}

Mice fasted for $12 \mathrm{~h}$ were divided into different groups, each containing six animals. One group was treated with saline $(10 \mathrm{ml} / \mathrm{kg})$, which served as a negative control and the next group was administered (CCh, $1 \mathrm{mg} /$ $\mathrm{kg}$ ) as the positive control. The next two groups were treated with increasing doses of Fp.Cr (30 and $100 \mathrm{mg}$ / $\mathrm{kg}$, orally, p.o.), acting as the test groups. After $15 \mathrm{~min}$ of treatment, each animal received $0.3 \mathrm{ml}$ of charcoal meal in the form of suspension in distilled water containing $10 \%$ gum acacia, $10 \%$ vegetable charcoal and $20 \%$ starch. The animals were sacrificed following 30 min of treatment, and the abdomen immediately cut opened to excise the whole small intestine. The length of the small intestine and the distance between the pylorus region and the front of the charcoal meal was measured to obtain the charcoal transport ratio or percentage. In order to assess the involvement of ACh-like prokinetic effect of the extract and CCh, respectively, further groups of mice were pretreated with atropine $(10 \mathrm{mg} / \mathrm{kg}$, intraperitoneal, i.p.) $15 \mathrm{~min}$ prior the administration of the extract or CCh [14].

\section{Laxative activity test}

Mice fasted for $6 \mathrm{~h}$ before the experiment were placed individually in cages lined with clean filter paper. The animals were divided into seven groups, each containing six animals; the first group acted as the negative control and was administered saline $(10 \mathrm{ml} / \mathrm{kg}$, p.o.), while the next group received CCh $(1 \mathrm{mg} / \mathrm{kg}$, i.p.), which served as the positive control. The next two third and fourth groups received oral doses of Fp.Cr (30 and $100 \mathrm{mg} / \mathrm{kg}$, respectively). To explore the possible mechanism of the laxative effect of the extract, three separate groups of mice were pretreated with atropine $(10 \mathrm{mg} / \mathrm{kg}$, i.p. $) 1 \mathrm{~h}$ 
before administration of the extract or CCh. After $18 \mathrm{~h}$, the feces production (total number of feces and total number of wet feces per group) in all animals was counted, and the percentage increase in wet feces relative to that of total fecal output was considered as the laxative effect [15].

\section{In-vitro experiments}

Gut preparations from mouse, guinea-pig and rabbit were obtained after sacrificing the animals through cervical dislocation; the abdomen was cut open, required tissues were identified and isolated out $[1,14,16]$, and the required tissue preparations of $2-3$ $\mathrm{cm}$ length were mounted in $10 \mathrm{ml}$ tissue baths containing the Tyrode's solution, maintained at $37{ }^{\circ} \mathrm{C}$ and aerated with a mixture of $5 \%$ carbon dioxide and $95 \%$ oxygen (carbogen). The composition of Tyrode's solution (mM) was $\mathrm{KCl} 2.68, \mathrm{NaCl} 136.9, \mathrm{MgCl}_{2}$ 1.05, $\mathrm{NaHCO}_{3}$ 11.90, $\mathrm{NaH}_{2} \mathrm{PO}_{4} 0.42, \mathrm{CaCl}_{2}$ 1.8, and glucose 5.55 ( $\mathrm{pH}$ 7.4). A preload of $1 \mathrm{~g}$ was applied to each tissue, and the contractile responses were recorded using isotonic transducer 50-6360 (Harvard Apparatus, Holliston, MA, USA) coupled with either a student oscillograph (Harvard Apparatus) or PowerLab (ML-845) data acquisition system (AD Instruments; Sydney, Australia) and a computer using chart software (version 5.3). The tissues were allowed to equilibrate for a period of $30 \mathrm{~min}$, and then stabilized with a sub-maximal concentration of $\mathrm{ACh}(0.3 \mu \mathrm{M})$. The tissues were presumed stable only after the reproducibility of the said responses. The plant extract was examined later for any spasmodic activity on the ileum and jejunum preparations of mouse, guinea-pig and rabbit at concentrations ranging from 0.01 to $5.0 \mathrm{mg} / \mathrm{ml}$.

\section{Statistical analysis}

All the data except $\mathrm{EC}_{50}$ values are expressed as mean \pm standard error of mean (S.E.M.), while " $n$ " represents number of animals/experiments). The median effective concentrations $\left(\mathrm{EC}_{50}\right.$ values) are geometric means with 95\% confidence intervals (CIs). One way analysis of variance (ANOVA) followed by Dunnett's test or unpaired $t$-test was used to assess the laxative activity, while oneway ANOVA followed by Tukey's test was employed for the effect of plant extract in charchoal meal transit. The concentration-response curves (CRCs) to the agonist responses were analysed by non-linear regression and two-way ANOVA followed by Bonferroni's post-test correction or unpaired $t$-test was used for multiple comparisons of CRCs with the respective control. All the graphing, calculations and statistical analysis were performed using GraphPad Prism 4 for windows (GraphPad Software, San Diego, California, USA).

\section{Results}

\section{Phytochemical analysis}

Preliminary phytochemical analysis of Fp.Cr revealed the presence of alkaloids, saponins, anthraquinones and tannins.

\section{In-vivo findings \\ Effect of Fp.Cr on charcoal meal GI transit in mice}

Fp.Cr, dose-dependently (30-100 mg/kg) propelled the charcoal meal through the small intestine of mice (Figure 1), thus showing prokinetic effect. The distance travelled by the vehicle control in saline was $58.9 \pm 1.7 \%$ (mean \pm S.E.M, $\mathrm{n}=6$ ) of total length of small intestine, while the positive control group receiving CCh $(1 \mathrm{mg} /$ $\mathrm{kg})$ significantly enhanced the movement $(\mathrm{p}<0.001$ versus saline) of charcoal meal to $96.3 \pm 1.8 \%$. The plant extract at the doses of 30 and $100 \mathrm{mg} / \mathrm{kg}$ significantly (p $<0.001$ ) enhanced the movement of charcoal meal to 71 $\pm 2.2 \%$ and $85.8 \pm 2.3 \%$ respectively, when compared with saline treated group $(58.9 \pm 1.7 \%)$. Pretreatment of animals with atropine $(1 \mathrm{mg} / \mathrm{kg})$ significantly reduced the prokinetic effect of the plant extract and CCh as shown in Figure 1.

\section{Laxative activity}

The treatment with Fp.Cr (30 and $100 \mathrm{mg} / \mathrm{kg}$ ) produced $61.2 \pm 2.2 \%$ and $71 \pm 3.2 \%$ (mean \pm S.E.M, $\mathrm{n}=6$ ) wet feces in mice. The positive control, CCh (1 mg/kg) produced $79.5 \pm 3.3 \%$ wet feces, while the saline treated group did not form any wet feces. Pretreatment of animals with Fp.Cr (30 and $100 \mathrm{mg} / \mathrm{kg}$ ) reduced wet feces to $30 \pm 4.3 \%$ and $10.6 \pm 5.0 \%$ respectively, while the reduction in $\mathrm{CCh}$-induced wet feces $(6.0 \pm 3.8 \%)$ was more pronounced as evident in Table 1.

\section{In-vitro findings}

\section{Effect of Fp.Cr on ileum preparation of different animals}

Fp.Cr at $0.01-0.3 \mathrm{mg} / \mathrm{ml}$ caused a stimulatory effect in isolated mouse ileum with efficacy of $62.5 \pm 2.2 \%$ of ACh maximum, as shown in Figure 2A. Pretreatment of the tissue with atropine $(0.1 \mu \mathrm{M})$ abolished the spasmogenic effect of Fp.Cr, while pretreatment of the tissue with hexamethonium, pyrilamine, or SB203186 had no effect (Figure 2A). The values determined in Figure 2A have been acquired from 4-7 separate experiments carried out on the isolated tissues of 4 animals.

In guinea-pig ileum, the plant extract caused stimulatory effect in a concentration-dependent $(0.01-3 \mathrm{mg} / \mathrm{ml})$ manner with maximum effect $(93.2 \pm 1 \%)$ reaching close to that of ACh maximum. Pretreatment of the tissue with atropine $(0.1 \mu \mathrm{M})$, but not with hexamethonium, pyrilamine, or SB203186, partially blocked ( $<<0.001$ ) the spasmogenic effect of Fp.Cr (Figure 2B). 


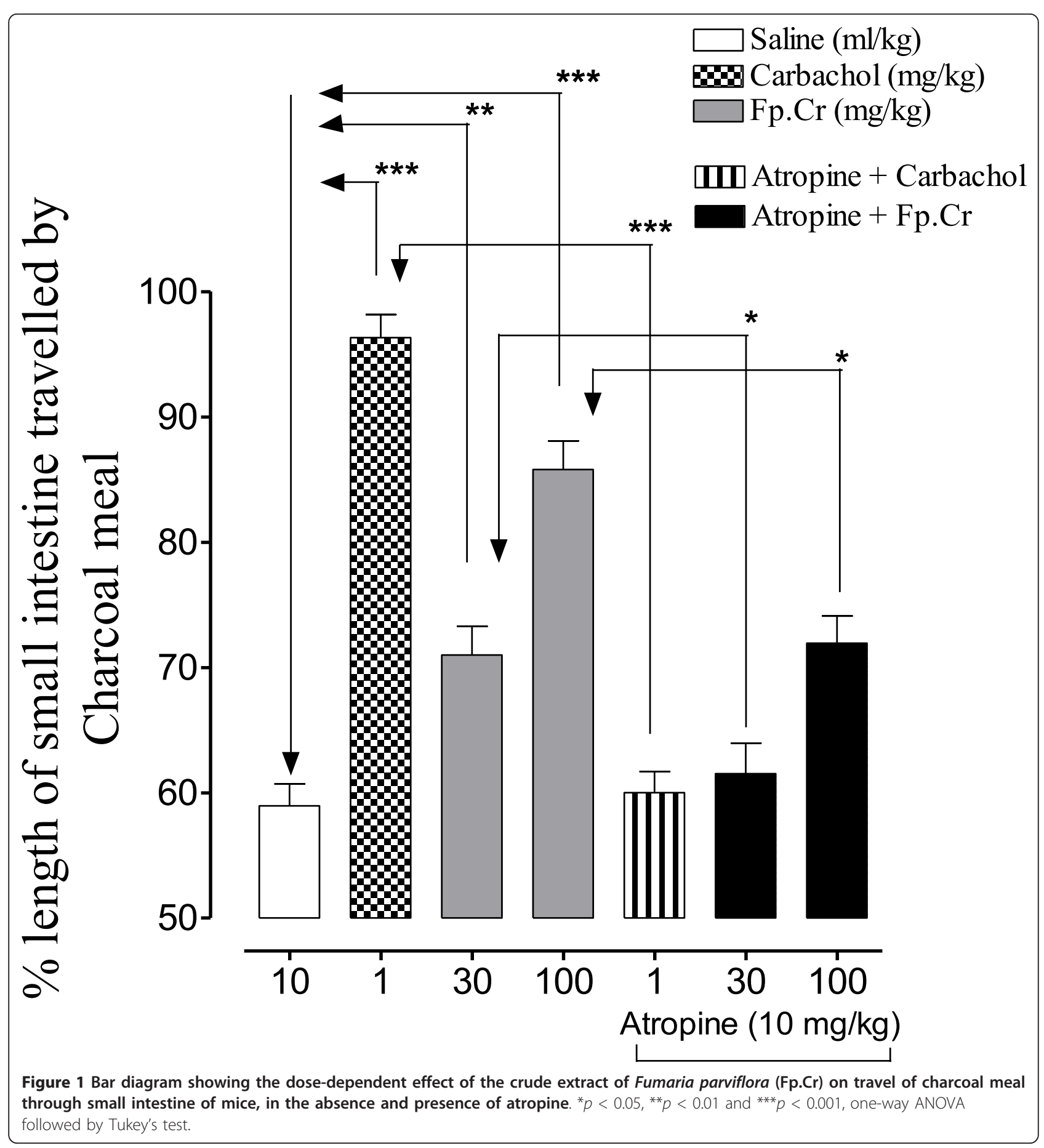

In rabbit ileum, Fp.Cr did not show any stimulatory effect on tested concentrations of $0.003-0.3 \mathrm{mg} / \mathrm{ml}$ (Figure $2 \mathrm{C}$ ).

\section{Effect of Fp.Cr on jejunum preparation of different} animals

In mouse jejunum, Fp.Cr, caused a concentrationdependent $(0.01-1 \mathrm{mg} / \mathrm{ml})$ stimulant effect with efficacy of $62 \pm 3 \%$ being less potent $(\mathrm{p}<0.05)$ than in mouse ileum. Pretreatment of the tissue with atropine $(0.1 \mu \mathrm{M})$ blocked the spasmogenic effect of Fp.Cr (Figure 2D).

In guinea-pig jejunum, $\mathrm{Fp} . \mathrm{Cr}(0.1-3 \mathrm{mg} / \mathrm{ml})$ exhibited a spasmodic effect reaching its maximum to $70 \pm 0.8 \%$ of ACh maximum, which was less than that obtained in ileum ( $<$ 0.05). Like in ileum, pretreatment of tissue with atropine partially blocked the stimulatory effect of 
Table 1 Laxative effect of the crude extract of Fumaria parviflora (Fp.Cr) without and with atropine in mice

\begin{tabular}{|c|c|c|c|c|c|}
\hline $\begin{array}{l}\text { Group } \\
\text { No. } \\
\end{array}$ & Treatment & $\begin{array}{l}\text { Dose }(\mathrm{mg} / \\
\mathrm{kg})\end{array}$ & $\begin{array}{l}\text { Mean defecation/ } \\
\text { group }\end{array}$ & $\begin{array}{l}\text { Mean number of wet feces/ } \\
\text { group }\end{array}$ & $\begin{array}{l}\text { Mean } \% \text { of wet } \\
\text { feces }\end{array}$ \\
\hline 1 & Saline (p.o., ml/kg) & 10 & $3 \pm 0.36$ & 0 & 0 \\
\hline 2 & Carbachol (i.p.) & 1 & $11.5 \pm 0.5^{* * *}$ & $9.1 \pm 0.5$ & $79.5 \pm 3.3$ \\
\hline 3 & Fp.Cr (p.o.) & 30 & $8.3 \pm 0.9^{* *}$ & $5.2 \pm 0.6$ & $61.2 \pm 2.2$ \\
\hline 4 & & 100 & $11.1 \pm 0.3^{* * *}$ & $8.0 \pm 1.0$ & $71.0 \pm 3.2$ \\
\hline 5 & $\begin{array}{l}\text { Carbachol (i.p.) + Atropine (i. } \\
\text { p.) }\end{array}$ & $1+10$ & $4.0 \pm 0.5^{* * *}$ & $0.3 \pm 0.2$ & $6.0 \pm 3.8$ \\
\hline 6 & Fp.Cr (p.o.) + Atropine (i.p.) & $30+10$ & $5.3 \pm 0.9^{* *}$ & $1.5 \pm 0.2$ & $30.0 \pm 4.3$ \\
\hline 7 & & $100+10$ & $4.6 \pm 0.6^{* * *}$ & $0.5 \pm 0.2$ & $10.6 \pm 5.0$ \\
\hline
\end{tabular}

Values shown are mean \pm S.E.M, $\mathrm{n}=6$. $^{* *} p<0.01$ and ${ }^{* * *} p<0.001$ show a comparison of group \# 2,3 and 4 vs. group \# 1 (One-way ANOVA followed by Dunnett's test), group \# 5 vs. group \# 2, group \# 6 vs. group \# 3 and group \# 7 vs. group \# 4 (unpaired t-test). The term p.o represent per oral, while i.p is for intraperitoneal injection.

Fp.Cr, while pretreatment with hexamethonium, pyrilamine or SB203186 had no influence on the stimulatory effect of Fp.Cr (Figure 2E).

When tested in spontaneously contracting rabbit jejunum, the plant extract exhibited a concentration-dependent $(0.01-0.3 \mathrm{mg} / \mathrm{ml})$ stimulatory effect. The efficacy of the spasmogenic effect was $78.1 \pm 3 \%$ of ACh maximum observed at $0.3 \mathrm{mg} / \mathrm{ml}$. Pretreatment of the tissue with atropine $(0.1 \mu \mathrm{M})$ completely blocked the spasmogenic effect of $\mathrm{Fp} . \mathrm{Cr}$, while the presence of hexamethonium, pyrilamine or SB203186 did not alter its effect (Figure 2F).

\section{Discussion}

When studied for its prokinetic and laxative effects in mice, the plant extract caused propulsion of charcoal meal through small intestine and increased the production of wet feces, similar to the effect of $\mathrm{CCh}$, a standard cholinergic agonist and accelerator of intestinal contents [17]. These gut stimulatory actions of the extract were partially suppressed when studied in the presence of atropine, a muscarinic receptor blocker [18], indicating the presence of some other gut stimulant constituent(s), in addition to ACh-like component(s). ACh is a neurotransmitter of the parasympathetic nervous system and is known to cause gastrointestinal stimulation through the activation of muscarinic receptors [17]; hence, the presence of ACh-like constituents explains its medicinal use in indigestion and constipation.

To further study the possible mode of the observed prokinetic and laxative actions of the extract, the invitro experiments were conducted. We used two different preparations (jejunum and ileum) from three different species (mouse, rabbit and guinea-pig), based on the previous observations that the plant extract do exhibit tissue and/or species-specific gut stimulatory effect $[14,19]$. Though efficacy for spasmodic effect of the plant extract varied in intestinal preparations from mouse (jejunum and ileum) and rabbit (jejunum), but its stimulant effect was completely blocked by atropine, thus, showing a common mechanism of gut stimulatory effect through cholinergic action, whereas, the insensitivity of rabbit ileum to stimulatory components of the extract might be due to its tissue selective effects or the presence of some other constituent of opposite mechanism more likely to be expressed in rabbit ileum. Similar tissue specific behavior was also seen in other medicinal herbs like, ginger [20], ispaghula [1] and black pepper [21].

While atropine completely blocked the stimulatory effect of plant extract in the isolated gut tissues of mice, however, only partially blocked the prokinetic and laxative effects of the plant extract in the in-vivo studies, which needs explanation. It is possible that the plant extract causes release of some endogenous gut stimulant mediator(s), other than cholinergic in nature.

In guinea-pig tissues, the observed stimulant effect of the plant extract was partially blocked by atropine, indicating that guinea-pig tissues behave differently from those of mouse and rabbit in the nature of gut stimulant effect, and clearly suggests some additional mechanism (s), independent of histamine, nicotine or 5-Hydroxytryptamine (5-HT, serotonin) receptors activation, which was evident by its insensitivity to pyrilamine, a histaminic type-1 $\left(\mathrm{H}_{1}\right)$ receptor blocker [22], hexamethonium, a ganglion blocker [23] or SB203186, a serotonergic receptor antagonist [24]. The other mechanisms known for their gut stimulant property, which have not been ruled out include, platelet activating factor [25], nitric-oxidedonating or releasing compounds [26] and dopaminergic antagonists [27].

Collectively, the data on jejunum and ileum preparations of mouse, rabbit and guinea-pig indicate a species and tissue-selective gut stimulatory effect of Fp.Cr. The observed stimulatory effect of the extract was fully atropine-sensitive in rabbit jejunum and mouse preparations, while guinea-pig tissues showed partial sensitivity to atropine. Rabbit ileum was insensitive to the 


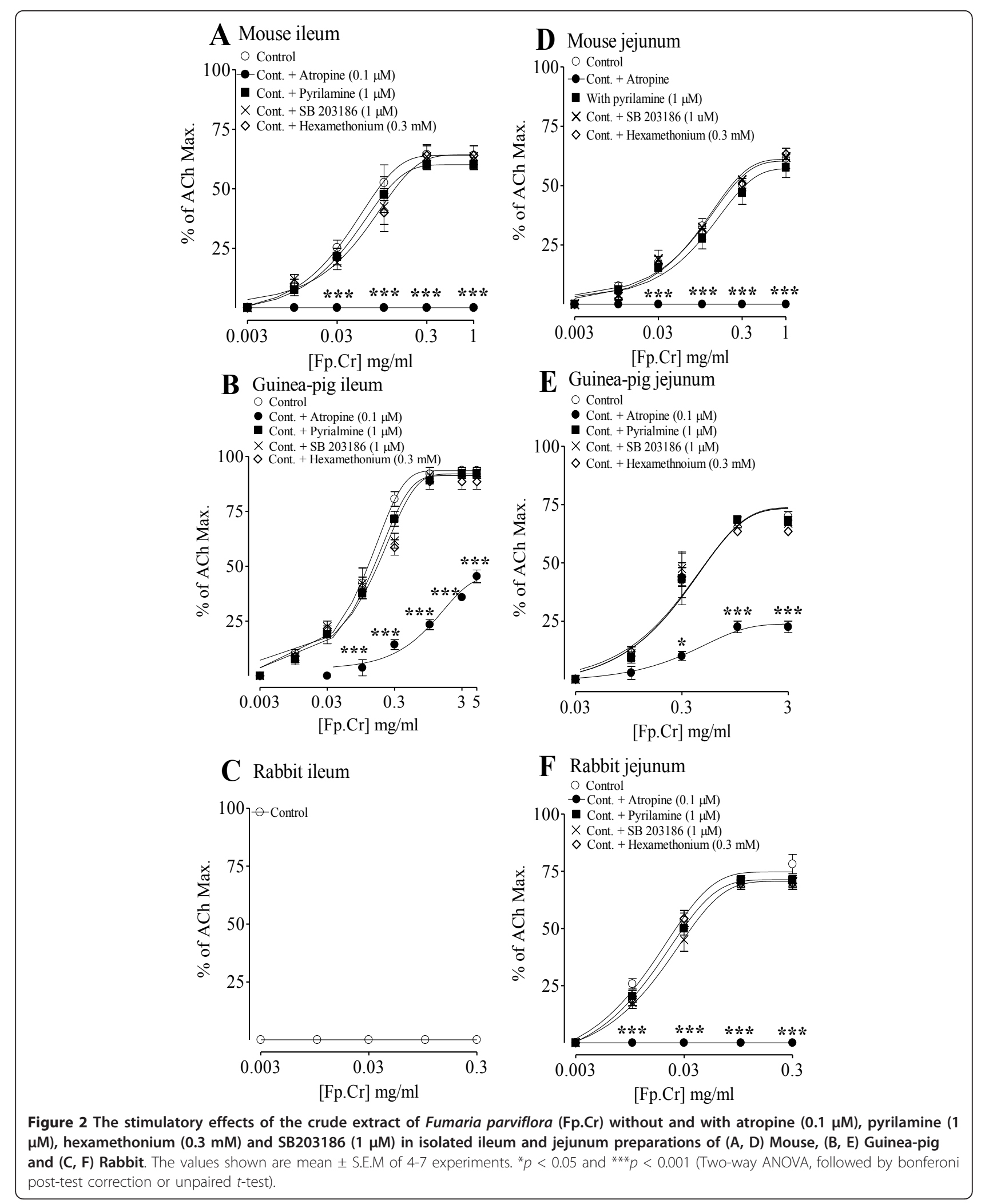


stimulatory effect of the plant extract, while guinea-pig tissues showed the highest efficacy, ileum being the most sensitive with efficacy close to that of ACh. Such types of species and/or tissue-selective effects of plant extracts have also been reported in earlier studies $[1,14,19,20,28,29]$. What is the pharmacological basis for this species and/or tissue specific behavior of some plant materials is not clear. Location and distribution of different subtypes of different receptors vary in different species and even difference exists within the tissues from the same species [30]. Furthermore, sometimes, compounds like atropine, which is not selective for any muscarinic receptor subtype, exhibits selective behavior in some species. For example, the potency of atropine is found to be less in rabbit tissues than in other species, which is believed to be due to the presence of atropinase enzyme in rabbit resulting in rapid metabolism of atropine, thus rendering it less active [31]. Similarly, the relatively high efficacy of the plant extract in guinea-pig tissues is possibly because of additional mechanism (non-cholinergic), which may involve activation of receptors, which are not present in other two species studied, though other possibilities cannot be ruled out.

Based on these observations, a suggestion can be made using different gut tissues from more than one species to know the broader picture. It may be worth mentioning that gut stimulant effect of $\mathrm{Fp}$.Cr was significantly (p $<0.001$ ) higher in rabbit jejunum and guinea-pig ileum, when compared with that of Fumaria indica, another species of Fumaria genus, which showed atropine-sensitive stimulant effects with no species or tissue selective behavior [7]. The observed variation in stimulatory effects of Fp.Cr (collected from Saudi Arabia), and Fumaria indica (collected from Pakistan), in guinea-pig ileum and rabbit jejunum could be either due to different plant-species or because of the effect of regional and environmental factors. The chemical composition and biological activity profile in the same plant grown in different regions are known to differ [32,33].

The plant has been shown to possess anthelmintic activity [34] and co-existence of laxative effect might be of added value in the expulsion of helminths, as the helminthes are known to promote developing gut disorders such as, abdominal pain, diarrhea, and constipation [35].

The presence of alkaloids, saponins [36] and anthraquinones [3] as the plant constituents, which are known to possess gut stimulatory properties, may explain the gut stimulant actions of the plant extract, though further studies are required to know the specific chemical(s) responsible for the tested biological activities.

\section{Conclusion}

This study showed that Fumaria parviflora possesses prokinetic and laxative activities of in mice, which were partially mediated through a cholinergic pathway. In the in-vitro studies, the observed spasmodic effect of the plant extract involved at least two pathways (atropinesensitive and insensitive) with species and tissue-selectivity, guinea-pig tissues being the most sensitive. This study provides sound pharmacological basis to the medicinal use of the plant in gut motility disorders, like indigestion and constipation, and suggests using more than one species to draw a meaningful conclusion, as no single species can truly represent human picture.

\section{Acknowledgements}

This study was initiated during the visit of A.H. Gilani to the King Saud University as a part of Visiting Professor Program, and partially supported by the Higher Education Commission, Government of Pakistan. In addition, this work was partially supported by Global Research Network for Medicinal Plants (GRNMP) and King Saud University.

\section{Author details}

'Natural Product Research Division, Department of Biological and Biomedical Sciences, The Aga Khan University Medical College, Karachi 74800, Pakistan. ${ }^{2}$ Department of Pharmacognosy, College of Pharmacy, King Saud University, Riyadh, Saudi Arabia. ${ }^{3}$ Department of Pharmacognosy|, Faculty of Pharmacy, Sana'a-University, Sana'a, Yemen.

\section{Authors' contributions}

AHG designed the project and supervised the study. NR carried out the experimental work, data analysis, literature search and drafted manuscript. MHM helped in study design, analysis of data and preparing draft manuscript. AJA and RAAM selected, identified and procured the plant material and corrected the manuscript for publication. All authors read and approved the final manuscript for publication.

\section{Competing interests}

The authors declare that they have no competing interests.

Received: 15 October 2011 Accepted: 10 March 2012 Published: 10 March 2012

\section{References}

1. Mehmood MH, Aziz N, Ghayur MN, Gilani AH: Pharmacological basis for the medicinal use of psyllium husk (Ispaghula) in constipation and diarrhea. Dig Dis Sci 2011, 56:1460-1471.

2. Gilani AH: Constipation and its treatment with natural drugs used in Pakistan. natural drugs and the digestive tract Rome: EMSI; 1992, 117-121.

3. Pasricha PJ: Goodman's and Gilman's: Treatment of disorders of bowel motility and water flux. the Pharmacological Basis of Therapeutics. 11 edition. New York: McGraw-Hill; 2006, 983-1008.

4. Gilani AH, Rahman A: Trends in Ethnopharmacology. J Ethnopharmacol 2005, 100:43-49.

5. Mossa JS, Al-Yahya MA, AlMeshal IA: Medicinal plants of Saudi Arabia. King Saud University Libraries Publications, Riyadh" 1 1987, ISBN: 9960-36476-3.

6. Baquar SR: Medicinal and poisonous plants of Pakistan. Printas, Karachi; 1989, 209-210.

7. Gilani AH, Bashir S, Janbaz KH, Khan A: Pharmacological basis for the use of Fumaria indica in constipation and diarrhea. J Ethnopharmacol 2005, 96:585-589.

8. Popova ME, Simanek V, Dolejs L, Smysl B, Preininger V: Alkaloids from Fumaria parviflora and Fumaria kralikii. Planta Med 1982, 45:120-122.

9. Rahman AU, Khati MK, Choudhary MI, Sener B: Chemical constituents of Fumaria indica. Fitoterapia 1992, 63:129-135.

10. Suau R, Cabezudo B, Rico R, Najera F, Lopez-Romero JM: Direct determination of alkaloid contents in Fumaria species by GC-MS. Phytochemical Anal 2002, 13:363-367.

11. Williamson EM, Okpako DT, Evans FJ: Pharmacological methods in phytotherapy research Chichester: John Wiley\& Sons; 1998, 15-23. 
12. Evans WC: Trease and Evans pharmacognos. 5 edition. Delhi: Elsevier; 2006 135-150.

13. National Research Council: Guide for the care and use of laboratory animal Washington, DC: National academy press; 1996, 1-5.

14. Rehman NU, Mehmood MH, Alkharfy KM, Gilani AH: Prokinetic and laxative activities of Lepidium sativum seed extract with species and tissue selective gut stimulatory actions. J Ethnopharmacol 2011, 126:480-486.

15. Méité S, Bahi C, Yéo D, Datté JY, Djaman JA, N'guessan DJ: Laxative activities of Mareya micrantha (Benth.) Müll. Arg. (Euphorbiaceae) leaf aqueous extract in rats. BMC Complement Altern Med 2010, 10:7.

16. Gilani AH, Mandukhail SU, Iqbal J, Yasinzai M, Aziz N, Khan A, Rehman NU: Antispasmodic and vasodilator activities of Morinda citrifolia root extract are mediated through blockade of voltage dependent calcium channels. BMC Complement Altern Med 2010, 10:2.

17. Brown JH, Taylor P: Goodman's and Gilman's: Cholinergic agonists. the pharmacological basis of therapeutics. 11 edition. New York: McGraw-Hill; 2006, 183-200

18. Gilani AH, Shaheen F, Christopoulos A, Mitchelson F: Interaction of ebeinone, an alkaloid from Fritillaria imperialis, at two muscarinic acetylcholine receptor subtypes. Life Sci 1997, 60:535-544.

19. Ghayur MN, Gilani AH: Species differences in the prokinetic effects of ginger. Int J Food Sci Nutr 2006, 57:65-73.

20. Ghayur MN, Gilani AH: Pharmacological basis for the medicinal use of Ginger in gastrointestinal disorders. Dig Dis Sci 2005, 50:1889-1897.

21. Mehmood MH, Gilani AH: Pharmacological basis for the medicinal use of black pepper and piperine in gastrointestinal disorders. J Med Food 2010, 13:1086-1096.

22. Sharif NA, Xu SX, Yanni JM: Histamine receptor-subtype affinities, selectivities, and potencies of emedastine, a novel $\mathrm{H}_{1}$-selective antagonist, and other ocularly employed antihistamines. Drug Dev Res 1994, 33:448-453.

23. Wien R, Mason DF, Edge ND, Langston GT: The ganglion blocking properties of homologous compounds in the methonium series. $\mathrm{Br} J$ Pharmacol 1952, 7:534-541.

24. Sander-Bush E, Mayer SE: Goodman's and Gilman's: 5-hydroxytryptamine (serotonin): agonist and antagonists. the pharmacological basis of therapeutics. 11 edition. New York: McGraw-Hill; 2006, 297-315.

25. Izzo AA, Gaginella TS, Mascolo N, Capasso F: Recent findings on the mode of action of laxatives: the role of platelet activating factor and nitric oxide. Trends Pharmacol Sci 1998, 19:403-405.

26. Mascolo N, Izzo AA, Avtore G, Barboto F, Capasso F: Nitric oxide and castor oil-induced diarrhea. J Pharmacol Exp Ther 1994, 268:291-295

27. Briejer MR, Akkermans LM, Schuurkes JA: Gastrointestinal prokinetic benzamides: the pharmacology underlying stimulation of motility. Pharmacol Rev 1995, 47:631-651.

28. McLeod RL, Gertner SB, Hey JA: Species differences in the cardiovascular responses to histamine $\mathrm{H}_{3}$ receptor activation. Eur J Pharmacol 1994, 259:211-214.

29. Ghayur MN, Gilani AH, Houghton PJ: Species differences in the gut stimulatory effects of radish seeds. J Pharm Pharmacol 2005, 57:1493-1501.

30. Ichida S, Oka H, Masada A, Fujisue T, Hata T, Matsuda N: Effects of synthetic omega-conotoxin on the contractile responses of segments of rat ileum, stomach fundus and uterus and guinea pig taenia coli. Jpn J Pharmacol 1988, 48:395-405.

31. Buckley GJ, DeCubellis J, Sharp CR, Rozanski EA: Cardiopulmonary Resuscitation in Hospitalized Rabbits: 15 cases. J Exot Pet Med 2011, 20:46-50.

32. Fluck $\mathrm{H}$ : The influence of the soil on the content of active principles in medicinal plants. J Pharm Pharmacol 1954, 6:153-163.

33. Flück $\mathrm{H}$ : The influence of climate on the active principles in medicinal plants. J Pharm Pharmacol 1955, 7:361-383.

34. Al-Shaibani IRM, Phulan MS, Sheikh M: Anthelmintic activity of Fumaria parviflora (Fumariaceae) against gastrointestinal nematodes of sheep. Int J Agric Biol 2009, 11:431-436.

35. Ortega CD, Ogawa NY, Rocha MS, Blasbalg R, Caiado AH, Warmbrand G, Cerri GG: Helminthic diseases in the abdomen: an epidemiologic and radiologic overview. Radiographics 2010, 30:253-267.

36. Akah PA, Oli AN, Enwerem NM, Gamaneil K: Preliminary studies on purgative effect of Carica papaya root extract. Fitoterapia 1997, 68:327-331.

\section{Pre-publication history}

The pre-publication history for this paper can be accessed here: http://www.biomedcentral.com/1472-6882/12/16/prepub

doi:10.1186/1472-6882-12-16

Cite this article as: Najeeb-ur-Rehman et al:: Species and tissuespecificity of prokinetic, laxative and spasmodic effects of Fumaria parviflora. BMC Complementary and Alternative Medicine 2012 12:16.

\section{Submit your next manuscript to BioMed Central and take full advantage of:}

- Convenient online submission

- Thorough peer review

- No space constraints or color figure charges

- Immediate publication on acceptance

- Inclusion in PubMed, CAS, Scopus and Google Scholar

- Research which is freely available for redistribution

Submit your manuscript at www.biomedcentral.com/submit
Ciomed Central 